\title{
PENGARUH GAYA BELAJAR DAN SIKAP SISWA PADA PELAJARAN MATEMATIKA TERHADAP HASIL BELAJAR MATEMATIKA
}

\author{
LENY HARTATI \\ leny_hartati@yahoo.co.id \\ Program Studi Pendidikan Matematika, Fakultas Teknik, Matematika \& IPA \\ Universitas Indraprasta PGRI
}

\begin{abstract}
Abstrak. Penelitian ini bertujuan untuk mengetahui pengaruh gaya belajar dan sikap siswa pada pelajaran matematika terhadap hasil belajar matematika. Metode penelitian yang digunakan adalah metode Expose Facto. Sampel penelitian ini diambil dari populasi terjangkau dengan teknik proporsional acak, yaitu sebanyak 60 siswa. Instrumen yang digunakan dalam penelitian ini adalah instrumen angket, untuk mengukur variabel gaya belajar dan variabel sikap siswa pada pelajaran matematika, serta instrumen tes, untuk mengukur hasil belajar matematika. Rancangan penelitian yang digunakan dalam penelitian ini adalah desain faktorial $3 \times 2$ dengan tiga variabel yang terdiri dari dua variabel bebas, yaitu gaya belajar kognitif dan sikap siswa pada pelajaran matematika, serta satu variabel terikat, yaitu hasil belajar matematika. Dari pengolahan data diperoleh hasil penelitian sebagai berikut: (1) Terdapat perbedaan hasil belajar matematika siswa yang memiliki gaya belajar visual, auditorial dan kinestetik. Hal ini di tunjukkan oleh harga $F$-hitung sebesar 2,494 dengan probabilitas sig 0,047 (sig $<0,05$ ) pada taraf signifikansi $\alpha=5 \%$. (2) Hasil belajar matematika siswa yang memiliki sikap positif pada pelajaran matematika lebih tinggi daripada siswa yang memiliki sikap negatif pada pelajaran matematika. Hal ini di tunjukkan oleh harga $F$-hitung sebesar 3,124 dengan probabilitas sig 0,018 ( sig < 0,05) pada taraf signifikansi $\alpha=5 \%$. (3) Tidak terdapat interaksi antara gaya belajar dengan sikap siswa pada pelajaran matematika terhadap hasil belajar matematika. Hal ini di tunjukkan oleh harga $F$-hitung interaksi adalah 1,621 sementara nilai probabilitas sig. untuk interaksi (gaya belajar*sikap siswa pada pelajaran matematika) sebesar 0,140 (sig > 0,05).
\end{abstract}

Kata Kunci: Gaya Belajar, Sikap, Hasil Belajar Matematika.

Abstract. This study aims to determine the effect of learning styles and attitudes of students in math on math learning outcomes. The method used is the method Expose Facto. The study sample drawn from a population with affordable proportional random technique, as many as 60 students. The instrument used in this study is a questionnaire instrument to measure learning style variables and variable attitudes of students in math, and test instruments, to measure the outcomes of learning mathematics. The research design used in this study is a $3 \times 2$ factorial design with three variables consisting of two independent variables, namely cognitive learning styles and attitudes of students in math, as well as the dependent variable, which is the result of learning mathematics. From the data processing obtained the following results: (1) There are differences in mathematics learning outcomes of students who have a visual learning style, auditory and kinesthetic. It is in the show by the price of the $F$ - count of 2,494 with a probability of 0.047 sig (sig $<0.05$ ) at significance level $\alpha=5 \%$. (2) The results of the mathematical learning of students who have a positive attitude at a higher math than students who have a negative attitude on math. It is in the show by the price of the $F$ - count of 3,124 with a probability of 0.018 sig (sig < 0.05) at significance level. (3) There is no interaction between the 
learning styles of students in math attitudes toward math learning outcomes. It is in the show by the price of the $F$ - calculated interaction probability value was 1.621 while sig. for interaction (learning styles $*$ attitude of students in math) of 0.140 (sig > 0.05).

Keywords: Learning Styles, Attitudes, Learning Outcomes Math.

\section{PENDAHULUAN}

Salah satu kecakapan dasar yang harus dimiliki oleh siswa ialah kecakapan matematika. Matematika mempunyai peran ganda, yaitu sebagai "The Queen of Science" atau sebagai ratu yang artinya dapat berdiri sendiri untuk pengembangan matematika itu sendiri; juga sebagai pelayan ilmu, yaitu matematika bermanfaat bagi perkembangan ilmu lainnya baik ilmu eksakta maupun ilmu sosial sesuai dengan perkembangan teknologi. Menyadari betapa pentingnya matematika, maka siswa dituntut agar dapat mempelajari matematika dengan sungguh-sungguh sehingga menghasilkan hasil belajar matematika yang baik bahkan memuaskan.

Pada kenyataannya banyak kita temui siswa dalam belajar matematika mengalami hambatan, prestasi yang tidak memuaskan dan lambat dalam mengerjakan tugas. Siswa tersebut dapat kita golongkan ke dalam siswa yang mengalami kesulitan belajar. Kesulitan belajar dapat disebabkan oleh faktor intern diantaranya sikap terhadap belajar, motivasi belajar, konsentrasi belajar, intelegensi dan minat. Sedangkan faktor ekstern diantaranya guru, sarana dan prasarana, lingkungan sosial siswa dan keluarga. Kesulitan belajar yang dialami siswa dalam mempelajari matematika di sekolah menengah, pada umumnya disebabkan kurangnya penguasaan konsep dasar matematika yang sudah diberikan sejak SD dan SMP. Penguasaan konsep dasar matematika secara mantap akan memberikan pemahaman yang kuat dalam menghadapi pelajaran selanjutnya. Proses belajar mengajar yang berlangsung di SD dan SMP memegang peranan penting dalam menanamkan konsep dasar matematika kepada siswa.

Salah satu hal yang harus diperhatikan oleh guru dalam mengajar adalah mengenal anak didik, mengetahui kemampuannya, minat dan keterbatasannya, gaya belajarnya agar apa yang diberikan dan cara penyampaian materi pelajaran dapat disesuaikan dengan keadaan anak didik. Untuk mengenali gaya belajar yang ada pada diri siswa, bukan merupakan hal yang sulit karena gaya belajar seseorang merupakan salah satu dari karakteristik individu yang belajar. Dengan kata lain, gaya belajar tercermin dari pribadi dan kemampuan seseorang.

Gaya belajar merupakan cara seseorang untuk menyerap, mengatur dan mengolah bahan informasi atau bahan pelajaran. Dalam merespon stimulus/informasi, ada siswa yang senang merespon informasi sendiri, tetapi ada pula siswa yang merespon informasi secara bersama-sama membentuk kelompok. Siswa yang mempunyai gaya belajar mandiri berusaha menyelesaikan masalahnya sendiri. Dengan demikian siswa tersebut dapat lebih termotivasi dalam belajar sehingga hasil belajarnya pun akan lebih baik.

Selain gaya belajar yang mempengaruhi keberhasilan seorang siswa belajar matematika, ada faktor lain yaitu guru, sarana belajar, dan lingkungan belajar. Faktorfaktor tersebut erat kaitannya dan saling mempengaruhi. Dikalangan siswa masih terdapat perbedaan pandangan terhadap matematika. Ada yang berpandangan baik dan ada yang berpandangan kurang baik. Hal ini tercermin dari keseharian siswa dalam belajar dan pelaksanaan tugas yang guru berikan kepada siswa.

Perbedaan pandangan siswa tersebut dapat dipengaruhi oleh pengalaman belajar siswa sebelumnya, di jenjang yang lebih rendah. Pengalaman itu bisa bermula dari guru yang di anggap tidak simpatik, tugas yang selalu bertumpuk, nilai matematika yang tidak penah bagus, atau matematika itu sendiri dianggap sebagai pelajaran yang sulit untuk di 
pahami. Sehingga pada saat ini siswa akan berhadapan kembali dengan pelajaran yang telah membuat pegalaman khusus bagi dirinya. Pengalaman belajar di jenjang sebelumnya akan berubah atau tetap, di tentukan oleh kondisi siswa dan faktor lain di luar diri siswa.

Walaupun tenaga pengajar dan sarana belajarnya baik, tetapi siswa tidak memanfaatkan dan menunjukkan sikap yang bersungguh-sungguh dalam belajar, tetap tidak akan tercapai hasil yang baik. Hasil belajar matematika lebih banyak ditentukan oleh faktor siswa sendiri. Disini siswa menjadi subyek utama dalam menentukan arah dan sikap belajarnya. Lengkapnya fasilitas dan tenaga pengajar yang berkualitas tidak akan menghasilkan hasil belajar yang baik jika siswa sendiri tidak bersungguh-sungguh dalam belajarnya.

Menurut penulis, siswa yang dapat mengombinasikan gaya belajarnya serta menunjukkan sikap yang positif terhadap pelajaran matematika akan meningkatkan hasil belajar matematika. Mengingat masih banyak siswa yang hasil belajar matematikanya kurang memuaskan disebabkan sikap siswa itu sendiri terhadap pelajaran matematika dan kurangnya mengoptimalkan dan mengombinasikan gaya belajar.

\section{TINJAUAN PUSTAKA}

\section{Hasil Belajar Matematika}

Belajar tidak hanya meliputi mata pelajaran, tetapi juga penguasaan, kebiasaan, persepsi, kesenangan, minat, penyesuaian, bermacam-macam keterampilan dan cita-cita. Belajar mengandung pengertian terjadinya perubahan dari persepsi dan perilaku, termasuk juga perbaikan perilaku. Tidak semua perubahan perilaku adalah belajar dan perubahan tidak selalu menghasilkan perbaikan ditinjau dari nilai-nilai sosial. Hilgard dan Brower seperti dikutip oleh Oemar Hamalik dalam bukunya yang berjudul Psikologi Belajar dan Mengajar (2004: 45) mendefisikan belajar sebagai perubahan dalam perbuatan melalui aktivitas, praktek, dan pengalaman. Slameto (2003: 2) mengatakan "Belajar adalah suatu usaha yang dilakukan individu untuk memperoleh suatu perubahan tingkah laku yang baru secara keseluruhan sebagai hasil pengalaman individu itu sendiri dalam interaksi dengan lingkungannya". W.S. Winkel (2004: 59) mengatakan "Belajar adalah suatu aktivitas mental atau psikis yang berlangsung dalam interaksi aktif dengan lingkungan yang menghasilkan perubahan dalam pengetahuan, pemahaman, keterampilan, dan nilai sikap. Perubahan itu bersifat secara relatif dan berbekas". Dengan demikian dapat disimpulkan, belajar adalah suatu proses yang menghasilkan perubahan baik tingkah laku, pengetahuan, pemahaman, keterampilan, kebiasaan sebagai usaha seseorang yang dapat diamati dan bersifat relatif konstan dan berbekas.

Hasil belajar merupakan akhir dari proses belajar, jadi seseorang bila ingin mencapai hasil belajar sudah pasti melalui proses belajar. Belajar atau tidaknya ditentukan dari sejauh mana siswa itu berupaya dalam menjalani kegiatan belajar tersebut. Oemar Hamalik (2002: 89) mengatakan "Hasil belajar nampak sebagai terjadinya perubahan tingkah laku pada diri siswa yang dapat diamati dan terukur dalam bentuk perubahan pengetahuan, sikap dan keterampilan. Perubahan tersebut diartikan sebagai terjadinya peningkatan dan pengembangan yang lebih baik". Hal ini senada dengan Bloom seperti dikutip oleh Suharsimi Arikunto dalam bukunya yang berjudul Dasardasar Evaluasi Pendidikan (2005: 117) membagi 3 macam hasil belajar menjadi 3 ranah, yaitu ranah kognitif, ranah afektif, ranah psikomotoris. Ketiga ranah tersebut menjadi obyek penilaian hasil belajar. Hordward Kingsley seperti dikutip oleh Nana Sudjana dalam bukunya yang berjudul Penilaian Hasil Proses Belajar (1995: 22) membagi 3 macam hasil belajar, yaitu keterampilan dan kebiasaan, pengetahuan dan pengertian, 
sikap dan cita-cita. Sedangkan Gagne dalam buku yang sama membagi 5 kategori hasil belajar, yaitu informasi verbal, keterampilan intelektual, strategi kognitif, sikap, dan keterampilan motoris. Belajar dan hasil belajar adalah dua hal yang saling berhubungan. Jika belajar merupakan suatu proses kegiatan atau perubahan, maka hasil belajar adalah suatu akibat dari proses kegiatan atau perubahan tingkah laku. Hasil belajar siswa pada hakikatnya adalah perubahan tingkah laku yang mencakup bidang kognitif, afektif, psikomotoris. Dengan demikian dapat disimpulkan, hasil belajar adalah perubahan tingkah laku siswa setelah mengalami proses belajar yang dapat diamati melalui aspek kognitif, aspek afektif, dan aspek psikomotorik.

Ruseffendi (1991: 15) berpendapat bahwa "Matematika adalah bahasa simbol; ilmu deduktif yang tidak menerima pembuktian secara induktif; ilmu tentang keteraturan dan struktur yang terorganisasi mulai dari unsur yang tidak didefinisikan ke unsur yang didefinisikan ke aksioma, postulat dan akhirnya ke dalil". John A. Van de Walle (2002: 12) mengatakan "Matematika adalah ilmu tentang pola dan urutan. Sebagai sesuatu yang sifatnya praktis, matematika tidak membahas tentang molekul dan sel, tetapi membahas tentang bilangan, kemungkinan, bentuk, algoritma dan perubahan. Sebagai ilmu dengan objek yang abstrak, matematika bergantung pada logika, bukan pada pengamatan sebagai standar kebenarannya, meskipun menggunakan pengamatan, simulasi dan bahkan percobaan sebagai alat untuk menemukan kebenaran". Jujun S. Suriasumantri (2007: 190) mengatakan "Matematika mengembangkan bahasa numerik yang memungkinkan untuk dilakukan pengukuran secara kuantitatif. Sifat kuantitatif ini meningkatkan daya prediktif dan kontrol dari ilmu hingga memberi jawaban yang lebih eksak yang memungkinkan pemecahan masalah yang tepat dan cermat." Dengan demikian dapat disimpulkan, matematika adalah ilmu tentang logika mengenai bentuk, susunan, besaran dan konsepkonsep yang saling berhubungan satu sama lainnya yang menggunakan istilah serta didefinisikan dengan cermat, jelas dan akurat untuk membantu manusia dalam memahami dan menguasai permasalahan sosial, ekonomi, dan alam.

Hasil belajar matematika adalah hasil akhir yang dimiliki oleh siswa berupa kemampuan-kemampuan dalam menguasai, memahami konsep dalam pelajaran matematika sebagai ilmu tentang logika mengenai bentuk, susunan, besaran dan konsepkonsep yang saling berhubungan satu sama lainnya yang menggunakan istilah serta didefinisikan dengan cermat, jelas dan akurat untuk membantu manusia dalam memahami dan menguasai permasalahan sosial, ekonomi, dan alam setelah melalui proses belajar.

\section{Gaya Belajar}

Belajar pada umumnya merupakan aktivitas individu untuk mencari dan memperoleh pengetahuan, pengalaman maupun informasi melalui bahan belajar ataupun dari lingkungan. Untuk mendapatkan pengetahuan, seseorang menggunakan cara belajar yang berbeda-beda. Cara belajar yang digunakan oleh seseorang dalam belajar disebut juga dengan gaya belajar.

Gaya belajar ditandai dengan cara konsisten siswa dalam merespon dan menggunakan stimulus yang diterimanya dalam aktivitas belajar, seperti yang dikatakan Witkin dalam Nasution (1988: 94), "learning style refers to student consistent way of responding to and using stimuli in the context of learning”. Untuk merespon stimulus yang berupa materi, bahan belajar, atau informasi diperlukan kemampuan mengindera, mengingat berpikir dan memecahkan masalah. Pendapat ini ditegaskan oleh Brown (1994: 105) yang mengungkapkan bahwa "learning style is the indicator of how learners perceire, interact whith and respon to the learning environment". Gaya belajar adalah petunjuk bagaimana mengamati, berinteraksi dan menanggapi lingkungan belajar. Deporter (1999: 110) dalam bukunya yang berjudul Quantum Learning mengatakan 
bahwa gaya belajar adalah "kombinasi dari bagaimana seseorang dapat menyerap dan kemudian mengatur serta mengolah informasi atau bahan pelajaran. Kemampuan menyerap dan mengatur informasi bagi setiap orang berbeda-beda dan sangat mempengaruhi gaya belajarnya. Selanjutnya Deporter (1999: 112) mengatakan bahwa berdasarkan modalitas, ada siswa yang senang belajar dengan menggunakan penglihatan, pendengaran atau gerakan. Modalitas individu adalah kemampuan mengindera untuk menyerap bahan informasi maupun bahan pelajaran. Gaya belajar berdasarkan modalitas ini terdiri dari tipe visual, auditori, dan kinestetik.

Meskipun banyak model-model gaya belajar yang dikemukakan, namun yang menjadi perhatian utama adalah gaya belajar berdasarkan modalitas individu. Pada kenyataanya kebanyakan orang memiliki ketiga gaya belajar modalitas ini, akan tetapi hampir semua orang cenderung pada salah satu gaya belajar yang berperan untuk pembelajaran, pemrosesan dan komunikasi.

Tipe gaya belajar siswa secara umum adalah sebagai berikut:

1. Gaya belajar visual

Gaya belajar ini mengandalkan aktivitas belajarnya kepada materi pelajaran yang dilihatnya. Pada gaya belajar visual ini yang memegang peranan penting dalam cara belajarnya adalah penglihatan. Peta pikiran/konsep dapat menjadi alat yang bagus bagi para pelajar visual karena mereka belajar terbaik saat mereka mulai dengan "gambaran keseluruhan", melakukan tinjauan umum megenai bahan pelajaran.

2. Gaya belajar auditorial

Gaya belajar ini mengandalkan aktivitas belajarnya kepada materi pelajaran yang didengarnya. Para pelajar auditori lebih suka merekam pada kaset daripada mencatat, karena mereka suka mendengarkan informasi berulang-ulang.

3. Gaya belajar kinestetik

Gaya belajar ini mengandalkan aktivitas belajarnya kepada gerakan. Para pelajar kinestetik suka belajar melalui gerakan, dan paling baik menghapal informasi dengan mengasosiasi gerakan dengan setiap fakta. Mereka lebih suka duduk di lantai dan menyebarkan pekerjaan di sekeliling mereka.

Dengan demikian dapat disimpulkan, gaya belajar adalah cara belajar seseorang dalam memperoleh pengetahuan, menyerap informasi, cara mengingat, berpikir dan memecahkan masalah secara berbeda-beda yang berkaitan dengan pribadi masing-masing sesuai dengan lingkungan belajarnya berdasarkan tiga tipe gaya belajar, yaitu visual, auditorial dan kinestetik.

\section{Sikap Siswa pada Pelajaran Matematika}

Sikap merupakan bagian yang tidak terlepas dari kehidupan manusia, karena tanpa adanya sikap tersebut sulit untuk dikatakan bahwa orang tersebut masih menjalankan fungsinya sebagai manusia. Sikap sangat diperlukan bagi seseorang untuk menilai dan meyakini sesuatu untuk merasakan senang atau tidak senang terhadap sesuatu dan untuk melakukan tindakan selanjutnya. Dengan sikap akan tercermin kepribadian seseorang.

Menurut Gene R. Hawes dan Lynne Salop hawes yang di kutip oleh The Liang Gie (1994: 25) sikap (attitude) dirumuskan sebagai "A general predisposition or mental set with regard to any persons, beliefs, or other entities; educational system typically seek to encourage the development of certain attitudes in their students, in addition to inculcating knowledge". (suatu kecenderungan umum atau kesiagaan mental dalam hubungannya dengan berbagai orang, keyakinan, atau entitas lainnya apapun; systemsistem pendidikan secara khas berusaha menganjurkan sikap-sikap tertentu pada muridmurid mereka sebagai tambahan dari menanamkan pengetahuan). Ellis (2007: 141) yang di kutip oleh Ngalim Purwanto dalam buku yang berjudul Psikologi Pendidikan 
mengatakan "Attitude involve some knowledge of sitation. However, the essential aspect of the attitude is found in the fact that some characteristic feeling or emotion is experienced, and as we would accordingly expect, some definite tendency to action is associated". (yang sangat memegang peranan penting di dalam sikap ialah factor perasaan atau emosi dan factor kedua adalah reaksi atau respons, atau kecenderungan untuk bereaksi).

Sikap terhadap pelajaran matematika dapat diartikan sebagai cara seseorang mereaksi terhadap pelajaran matematika baik di sekolah maupun di luar sekolah. Selain itu sikap siswa terhadap pelajaran matematika juga akan menentukan apakah siswa tersebut mereaksi positif atau negatif terhadap pelajaran matematika. Sikap ini akan membedakan pula pelajaran matematika dengan pelajaran lainnya. Jika siswa mempunyai sikap positif terhadap pelajaran matematika maka dia akan mengkategorikan matematika sebagai pelajaran yang menarik serta bermanfaat untuk di pelajari. Sebaliknya, jika siswa mereaksi negatif terhadap pelajaran matematika maka dia akan mengkategorikan pelajaran matematika sebagai pelajaran yang tidak menarik dan kurang bermanfaat untuk di pelajari. Dari uraian tersebut, bahwa sikap siswa terhadap pelajaran matematika dapat dibedakan menjadi dua, yaitu:

1. Siswa yang memiliki sikap positif terhadap pelajaran matematika, antara lain:

a. Suka atau senang terhadap pelajaran matematika.

b. Selalu mengerjakan PR/tugas yang diberikan guru..

c. Mengikuti pelajaran dengan sungguh-sungguh.

d. Merespon dengan baik masalah dan tantangan yang datang dari pelajaran matematika.

e. Menjalin hubungan yang kooperatif dengan guru matematika.

2. Siswa yang memiliki sikap negatif terhadap pelajaran matematika, antara lain:

a. Tidak senang terhadap pelajaran matematika.

b. Mengerjakan PR/tugas yang diberikan guru dengan terpaksa atau bahkan tidak mengerjakan PR sama sekali.

c. Mengikuti pelajaran dengan sikap acuh tak acuh.

d. Belajar jika hanya ada ulangan saja.

e. Malas mengerjakan soal-soal matematika

f. Kurang dapat menjalin hubungan yang kooperatif dengan guru matematika.

\section{METODE}

Metode yang dilakukan dalam penelitian ini adalah metode expose facto. Menurut Kerlinger penelitian expose facto adalah penyelidikan empiris yang sistematis dimana ilmuwan tidak mengendalikan variabel bebas secara langsung karena eksistensi dari variabel tersebut telah terjadi, atau karena variabel tersebut pada dasarnyatidak dapat dimanipulasi. Penelitian ini dipertimbangkan sebagai expose facto atau kausal komparatif dengan alasan bahwa faktor-faktor yang dijaring dari ketiga variable penelitian sudah terjadi di lapangan dan peneliti tinggal mengumpulkan data diantaranya gaya belajar dan sikap siswa terhadap pelajaran matematika. Kelemahan utama dalam penelitian expose facto yaitu pertama peneliti tidak mampu memanipulasi variabel bebas secara sengaja dan kedua peneliti tidak dapat menetapkan subjek-subjek secara acak pada tingkat kelompok variabel yang diteliti.

Adapun rancangan penelitian tersebut menggunakan anova dua jalur dengan faktorial 3 x 2 sebagai berikut: 


\begin{tabular}{|c|c|c|c|}
\hline Sikap & Positif & Negatif & $\sum \mathrm{B}$ \\
\hline Gava Belaiar & & $\mathrm{Y}_{12}$ & $\mathrm{Y}_{10}$ \\
\hline Visual & $\mathrm{Y}_{21}$ & $\mathrm{Y}_{22}$ & $\mathrm{Y}_{20}$ \\
\hline Auditorial & $\mathrm{Y}_{31}$ & $\mathrm{Y}_{32}$ & $\mathrm{Y}_{30}$ \\
\hline Kinestetik & $\mathrm{Y}_{01}$ & $\mathrm{Y}_{02}$ & $\mathrm{Y}_{03}$ \\
\hline$\sum-\mathrm{K}$ & &
\end{tabular}

Gambar 1. Desain penelitian

\section{HASIL DAN PEMBAHASAN \\ Analisis Statistik Deskriptif}

Berdasarkan penelitian yang telah dilakukan di SMK pada kecamatan Jagakarsa diperoleh hasil penelitian sebagai berikut:

Hasil belajar matematika siswa yang memiliki gaya belajar visual diperoleh skor terendah 53 dan tertinggi 80, nilai rata-rata/mean 65,45, median sebesar 63, modus sebesar 63, varians sebesar 80,080 dan simpangan baku sebesar 8,947. Sedangkan hasil belajar matematika siswa yang memiliki gaya belajar auditorial diperoleh skor terendah 53 dan tertinggi 80, nilai rata-rata/mean 65,25, median sebesar 63, modus sebesar 60, varians sebesar 70,829 dan simpangan baku sebesar 8,416. Selanjutnya hasil belajar matematika siswa yang memiliki gaya belajar kinestetik diperoleh skor terendah 53 dan tertinggi 80 , nilai rata-rata/mean 66,80, median sebesar 65 , modus sebesar 60 , varians sebesar 68,589 dan simpangan baku sebesar 8,282.

Hasil belajar matematika siswa yang memiliki sikap positif diperoleh skor terendah 53 dan tertinggi 80, nilai rata-rata/mean 66,50, median sebesar 63, modus sebesar 63, varians sebesar 76,833, dan simpangan baku sebesar 8,765. Sedangkan hasil belajar matematika siswa yang memiliki sikap negatif diperoleh skor terendah 53 dan tertinggi 80, nilai rata-rata/mean 65,17, median sebesar 63, modus sebesar 60, varians sebesar 67,017 dan simpangan baku sebesar 8,186.

Dari data statistik secara empirik tersebut di atas dapat disimpulkan hasil belajar matematika yang memiliki gaya belajar visual, auditorial dan kinestetik memiliki skor terendah dan tertinggi serta nilai modus yang hampir sama atau tidak signifikan perbedaannya. Hal tersebut juga ditunjukkan oleh nilai rata-rata pada ketiga gaya belajarnya dengan gaya belajar kinestetik yang paling tinggi diantara ketiganya dengan nilai rata-rata sebesar 66,80 . Selanjutnya hasil belajar untuk sikap siswa pada pelajaran matematika dapat disimpulkan hasil belajar matematika yang memiliki sikap positif lebih baik daripada hasil belajar matematika yang memiliki sikap negatif. Hal ini ditunjukkan dengan nilai rata-rata sebesar 66,50 dan modus sebesar 63 .

\section{Uji Persyaratan Analisis Data \\ Uji normalitas}

Berdasarkan perhitungan diperoleh nilai sig untuk hasil belajar matematika siswa yang memiliki gaya belajar visual sebesar 0,140 ; nilai sig untuk hasil belajar matematika siswa yang memiliki gaya belajar auditorial sebesar 0,368; nilai sig untuk hasil belajar matematika siswa yang memiliki gaya belajar kinestetik sebesar 0,559 ; nilai sig untuk hasil belajar matematika siswa yang memiliki sikap positif sebesar 0,081 ; nilai sig untuk hasil belajar matematika siswa yang memiliki sikap negatif sebesar 0,186. Dari hasil ini diperoleh kesimpulan bahwa nilai sig untuk seluruh kelompok di atas 0,05 (sig > 0,05); sehingga dapat disimpulkan bahwa data berdistribusi normal, sehingga proses analisis data dapat dilakukan dengan menggunakan statistik parametrik. 


\section{Uji Homogenitas}

Berdasarkan perhitungan diperoleh nilai sig untuk hasil belajar matematika siswa yang memiliki gaya belajar visual $=0,618$; nilai sig untuk hasil belajar matematika siswa yang memiliki gaya belajar auditorial $=0,141$; nilai sig untuk hasil belajar matematika siswa yang memiliki gaya belajar kinestetik $=0,105$. Dari hasil ini diperoleh kesimpulan bahwa nilai sig untuk seluruh kelompok gaya belajar di atas 0,05 (sig > 0,05) sehingga dapat disimpulkan bahwa sampel berasal dari populasi yang memiliki varians homogen. Sedangkan untuk kelompok sikap siswa pada pelajaran matematika diperoleh nilai sig untuk hasil belajar matematika siswa yang memiliki sikap positif $=0,161$; nilai sig untuk hasil belajar matematika siswa yang memiliki sikap negatif $=0,397$. Dari hasil ini diperoleh kesimpulan bahwa nilai sig untuk seluruh kelompok sikap siswa pada pelajaran matematika di atas 0,05 (sig > 0,05) sehingga dapat disimpulkan bahwa sampel berasal dari populasi yang memiliki varians homogen.

\section{Uji Hipotesis}

1. Terdapat perbedaan hasil belajar matematika siswa yang memiliki gaya belajar visual, auditorial, dan kinestetik

$\mathrm{H}_{0}: \mu \mathrm{B}_{1}=\mu \mathrm{B}_{2}=\mu \mathrm{B}_{3}$

$\mathrm{H}_{1}: \mu \mathrm{B}_{1} \neq \mu \mathrm{B}_{2} \neq \mu \mathrm{B}_{3}$

Data yang diperoleh pada hasil pengukuran gaya belajar siswa terhadap hasil belajar matematika menunjukkan bahwa nilai rata-rata skor hasil belajar matematika siswa yang memiliki gaya belajar visual adalah 65,45 sementara nilai rata-rata skor hasil belajar matematika siswa yang memiliki gaya belajar auditorial adalah 65,25; sedangkan nilai rata-rata skor hasil belajar matematika siswa yang memiliki gaya belajar kinestetik adalah 66,80. Jika ketiga nilai rata-rata tersebut dibandingkan, terlihat bahwa nilai rata-rata hasil belajar matematika siswa yang memiliki gaya belajar kinestetik lebih tinggi daripada nilai rata-rata hasil belajar matematika siswa yang memiliki gaya belajar visual dan auditorial.

2. Hasil belajar matematika siswa yang memiliki sikap positif pada pelajaran matematika lebih tinggi daripada siswa yang memiliki sikap negatif pada pelajaran matematika.

$\mathrm{H}_{0}: \mu \mathrm{A}_{1} \leq \mu \mathrm{A}_{2}$

$\mathrm{H}_{1}: \mu \mathrm{A}_{1}>\mu \mathrm{A}_{2}$

Data yang diperoleh pada hasil pengukuran sikap siswa pada pelajaran matematika terhadap hasil belajar matematika menunjukkan bahwa nilai rata-rata skor hasil belajar matematika siswa yang memiliki sikap positif pada pelajaran matematika adalah 66,50 sementara nilai rata-rata skor hasil belajar matematika siswa yang memiliki sikap negatif pada pelajaran matematika adalah 65,17 . Jika kedua nilai rata-rata tersebut dibandingkan, terlihat bahwa nilai rata-rata hasil belajar matematika siswa yang memiliki sikap positif pada pelajaran matematika lebih tinggi daripada nilai rata-rata hasil belajar matematika siswa yang memiliki sikap negatif pada pelajaran matematika.

3. Terdapat pengaruh interaksi antara gaya belajar dan sikap siswa pada pelajaran matematika terhadap hasil belajar matematika.

$\mathrm{H}_{\mathrm{o}}$ : Interaksi A X B $=0$

$\mathrm{H}_{1}$ : Interaksi A X B $\neq 0$

Berdasarkan perhitungan dapat diperoleh harga $F$-hitung interaksi adalah 1,621 sementara nilai probabilitas sig. untuk interaksi (gaya belajar*sikap siswa pada pelajaran matematika) sebesar 0,140 (sig > 0,05). Berdasarkan hasil tersebut, maka hipotesis nol $\left(\mathrm{H}_{0}\right)$ diterima dan hipotesis alternatif $\left(\mathrm{H}_{1}\right)$ ditolak. Hal ini membuktikan 
bahwa tidak terdapat interaksi antara gaya belajar dan sikap siswa pada matematika terhadap hasil belajar matematika.

\section{Pembahasan}

\section{Pengaruh Gaya Belajar Terhadap Hasil Belajar Matematika.}

Hasil penelitian pada hasil belajar matematika pada siswa yang memiliki gaya belajar yang berbeda menunjukkan adanya perbedaan hasil belajar matematika antara kelompok siswa yang memiliki gaya belajar visual $\left(\mathrm{B}_{1}\right)$ dengan kelompok siswa yang memiliki gaya belajar auditorial $\left(\mathrm{B}_{2}\right)$ dan kelompok siswa yang memiliki gaya belajar kinestetik $\left(\mathrm{B}_{3}\right)$. Perbedaan ini dapat dilihat dari perbedaan nilai rata-rata skor hasil belajar matematika yang diperoleh setiap kelompok tersebut. Nilai rata-rata hasil belajar matematika kelompok siswa yang memiliki gaya belajar kinestetik $\left(\mu \mathrm{B}_{3}=66,80\right)$ lebih tinggi daripada nilai rata-rata hasil belajar matematika siswa yang memiliki gaya belajar visual $\left(\mu B_{1}=65,45\right)$ dan auditorial $\left(\mu B_{2}=65,25\right)$. Perbedaan ini juga diperkuat dengan hasil ANAVA yang memperlihatkan harga $F$-hitung sebesar 2,494 dengan probabilitas sig 0,047 (sig $<0,05$ ) pada taraf signifikansi $\alpha=5 \%$. Hasil ini memperkuat asumsi bahwa gaya belajar siswa yang berbeda akan memberikan hasil belajar matematika yang berbeda pula.

Setiap siswa memiliki gaya belajar yang berbeda. Untuk itu dalam menyampaikan materi pelajaran dalam hal ini matematika di perlukan kreatifitas seorang guru agar dapat menciptakan sebuah pengajaran yang menyenangkan bagi seluruh siswanya. Selain data di atas, ada data lain yang menunjang asumsi tersebut yaitu data perolehan nilai rata-rata skor hasil belajar matematika dilakukan siswa. Berdasarkan data yang diperoleh dari hasil tes terlihat bahwa kelompok siswa yang memiliki gaya belajar kinestetik $\left(\mathrm{B}_{3}\right)$ memperoleh nilai rata-rata skor akhir sebesar 66,80 sementara kelompok siswa yang memiliki gaya belajar visual $\left(B_{1}\right)$ hanya mendapatkan skor akhir sebesar 65,45 ; dan kelompok siswa yang memiliki gaya belajar auditorial $\left(\mathrm{B}_{2}\right)$ memperoleh nilai rata-rata skor sebesar 65,25. Berdasarkan data di atas, maka kesimpulan yang diperoleh melalui analisis statistik secara empirik terbukti bahwa terdapat perbedaan antara ketiga kelompok siswa yang memiliki gaya belajar visual, auditorial dan kinestetik.

\section{Pengaruh Sikap Siswa Pada Matematika Terhadap Hasil Belajar Matematika.}

Pada kelompok Sikap siswa pada pelajaran matematika yang berbeda yaitu sikap positif dan sikap negatif, perbedaan sikap siswa pada pelajaran matematika terhadap hasil belajar matematika ditunjukkan oleh perbedaan nilai rata-rata skornya. Nilai rata-rata hasil belajar kelompok siswa yang memiliki sikap positif pada pelajaran matematika $\left(\mu \mathrm{A}_{1}\right.$ $=66,50)$ lebih tinggi dari pada nilai rata-rata hasil belajar matematika kelompok siswa yang memiliki sikap negative pada pelajaran matematika $\left(\mu \mathrm{A}_{2}=65,17\right)$. Perbedaan ini juga diperkuat dengan hasil ANAVA yang memperlihatkan harga $F$-hitung sebesar 3,124 dengan probabilitas sig $0,018(\operatorname{sig}<0,05)$ pada taraf signifikansi $\alpha=5 \%$. Hasil ini memperkuat asumsi bahwa sikap siswa pada matematika yang berbeda akan memberikan hasil belajar matematika yang berbeda pula.

Siswa yang memiliki sikap positif pada pelajaran matematika cenderung mendapatkan hasil belajar yang baik, sementara siswa yang memiliki sikap negatif pada pelajaran matematika cenderung kurang memuaskan. Selain data di atas, ada data lain yang menunjang asumsi tersebut yaitu data perolehan nilai rata-rata skor akhir tes yang dilakukan siswa. Berdasarkan data yang diperoleh dari hasil tes, terlihat bahwa kelompok siswa yang memiliki sikap positif pada pelajaran matematika $\left(\mathrm{A}_{1}\right)$ memperoleh nilai ratarata skor akhir sebesar 66,50 sementara kelompok siswa yang memiliki sikap negatif pada pelajaran matematika $\left(\mathrm{A}_{2}\right)$ hanya mendapatkan skor akhir sebesar 65,17 . Berdasarkan 
data di atas, maka kesimpulan yang diperoleh melalui analisis statistik secara empirik terbukti bahwa kelompok siswa yang memiliki sikap positif pada pelajaran matematika memiliki nilai rata-rata hasil belajar matematika yang lebih tinggi dibandingkan dengan kelompok siswa yang memiliki sikap negatif pada pelajaran matematika.

\section{Pengaruh Interaksi antara Gaya Belajar dan Sikap Siswa Pada Matematika Terhadap Hasil Belajar Matematika.}

Pada penelitian ini, tidak terdapat interaksi antara gaya belajar dan sikap siswa pada pelajaran matematika terhadap hasil belajar matematika. Hal ini terlihat dari hasil ANAVA, yaitu harga $F$-hitung interaksi adalah adalah 1,621 sementara nilai probabilitas sig. untuk interaksi (gaya belajar dan sikap siswa pada pelajaran matematika terhadap hasil belajar matematika) sebesar 0,140 ( $\mathrm{sig}>0,05$ ). Berdasarkan penjelasan di atas, maka kesimpulan yang diperoleh melalui analisis statistik secara empirik terbukti bahwa tidak terdapat interaksi antara gaya belajar dan sikap siswa pada pelajaran matematika terhadap hasil belajar matematika. Hal ini disebabkan oleh banyak faktor, salah satu diantaranya adalah faktor pengisian instrumen yang kurang sungguh-sungguh.

\section{PENUTUP}

\section{Simpulan}

Adapun kesimpulan yang dapat diambil dari penelitian ini berdasarkan hasil pengujian hipotesis dan pembahasan hasil penelitian adalah sebagai berikut:

1. Terdapat perbedaan antara hasil belajar matematika siswa yang memiliki gaya belajar visual, auditorial dan kinestetik. Kelompok siswa yang memiliki gaya belajar kinestetik memiliki nilai rata-rata skor hasil belajar matematika yang lebih tinggi di bandingkan dengan nilai rata-rata skor hasil belajar matematika siswa yang memiliki gaya belajar visual dan auditorial. Nilai rata-rata skor hasil belajar matematika siswa yang memiliki gaya belajar visual adalah 65,45 sementara nilai rata-rata skor hasil belajar matematika siswa yang memiliki gaya belajar auditorial adalah 65,25; sedangkan nilai rata-rata skor hasil belajar matematika siswa yang memiliki gaya belajar kinestetik adalah 66,80. Ini ditunjukkan oleh output SPSS hasil ANAVA diperoleh harga $F$-hitung sebesar 2,494 dengan probabilitas sig sebesar 0,047 (sig < $0,05)$ pada taraf signifikansi $\alpha=5 \%$.

2. Hasil belajar matematika siswa yang memiliki sikap positif pada pelajaran matematika lebih tinggi daripada siswa yang memiliki sikap negatif pada pelajaran matematika. Nilai rata-rata skor hasil belajar matematika siswa yang memiliki sikap positif pada pelajaran matematika lebih tinggi daripada hasil belajar matematika siswa yang memiliki sikap negatif pada pelajaran matematika. Nilai rata-rata skor hasil belajar matematika siswa yang memiliki sikap positif pada pelajaran matematika adalah 66,50 sementara nilai rata-rata skor hasil belajar matematika siswa yang memiliki sikap negative pada pelajaran matematika adalah 65,17 . Ini ditunjukkan oleh output SPSS hasil ANAVA diperoleh harga $F$-hitung sebesar 3,124 dengan probabilitas sig sebesar $0,018($ sig $<0,05)$ pada taraf signifikansi $\alpha=5 \%$.

3. Tidak Terdapat interaksi antara gaya belajar dan sikap siswa pada pelajaran matematika terhadap hasil belajar matematika.

Berdasarkan hasil output SPSS diperoleh harga $F$-hitung interaksi adalah 1,621 sementara nilai probabilitas sig. untuk interaksi (gaya belajar dan sikap siswa pada pelajaran matematika terhadap hasil belajar matematika) sebesar 0,140 (sig > 0,05). Berdasarkan hasil tersebut, dapat disimpulkan bahwa tidak terdapat interaksi antara gaya belajar dan sikap siswa pada matematika terhadap hasil belajar matematika. Hal 
ini disebabkan oleh banyak faktor, salah satunya kurangnya siswa menjawab instrumen dengan jujur,dan sungguh-sungguh.

\section{Saran}

Penelitian tentang pengaruh gaya belajar dan sikap siswa pada pelajaran matematika terhadap hasil belajar matematika ini tentunya mempunyai kelemahan baik secara konseptual maupun secara metodelogis. Beberapa saran yang dapat diberikan untuk instansi sekolah dan rekan-rekan peneliti yang akan mengembangkan dan meningkatkan kualitas penelitian dengan topik serupa atau sejenis, maka ada beberapa hal yang dapat diperhatikan berikut ini:

1. Siswa sebagai individu memiliki ketiga gaya belajar yang saling mendukung walaupun terdapat kecenderungan pada salah satu tipe, oleh karena itu siswa diharapkan dapat mengkombinasikan ketiga gaya belajar tersebut sehingga dampaknya akan meningkatkan hasil belajar matematika.

2. Guru sebagai unsur terpenting dalam proses pembelajaran harus berusaha untuk menampilkan proses pembelajaran yang menyenangkan, hal ini tentunya akan meningkatkan motivasi dan minat siswa pada matematika yang dampaknya di harapkan dapat meningkatkan hasil belajarnya.

3. Seluruh elemen pendidikan, siswa, orang tua, guru dan pemerintah mengupayakan agar siswa memiliki sikap yang positif terhadap matematika karena dengan memiliki sikap yang positif terhadap matematika diharapkan dapat meningkatkan hasil belajar matematika.

4. Bagi peneliti selanjutnya yang akan meneliti dan mengembangkan dengan topik yang sama, diharapkan dapat membuat alat ukur yang lebih spesifik dan bahasa yang lebih sederhana sehingga mudah dipahami siswa. Selain itu untuk meningkatkan korelasi antar faktor dari setiap instrument penelitian, kiranya dapat dibuat atau didesain alat ukur yang lebih baik.

\section{DAFTAR PUSTAKA}

Abdurahman, Mulyono. 1999. Pendidikan Bagi Anak Berkesulitan Belajar. Jakarta: Rineka Cipta.

Ahmadi, Abu. 1999. Psikologi Sosial. Jakarta: Rineka Cipta.

Arikunto, Suharsimi. 2005. Dasar-dasar Evaluasi. Jakarta: Bumi Aksara.

Deporter, Bobbi. 1999. Quantum Learning. Bandung: Kaifa.

Dunn, Rita. Dunn, Kenneth. Perrin Jannet. 1994. Teaching Young Children Through Their Individual Learning Styale. United State of America (USA): Allyn and Bacon.

Ellis, Roberts S. 2007. Educational Psychology: A Problem Approach, D. Van Nostrand Company, Inc., New Jersey, London, New York.

Hamalik, Oemar. 2002. Psikologi Belajar dan Mengajar. Bandung: Sinar Baru Algesindo.

John A. Van de Walle. 2002. Matematika Sekolah Dasar dan Menengah Pengembangan Pengajaran. Jakarta: Erlangga.

Nasution, S. 1988. Berbagai Pendekatan dalam Proses Belajar Mengajar. Jakarta: Bina Aksara Citra.

Prashnig, Barbara. 2007. The Power of Learning Style. Bandung: Kaifa.

Purwanto, M. Ngalim. 1990. Psikologi Pendidikan. Bandung: Remaja Rosdakarya.

Riduwan. 2003. Dasar-Dasar Statistika. Bandung: Alfabeta.

Russefendi, E.T., 1991. Pengantar Kepada Membantu Guru Mengembangkan Kompetensinya Dalam Pengajaran Matematika CBSA. Bandung: Tarsito. 
Santoso, Singgih. 2010. Panduan Lengkap Menguasai Statistik Dengan SPSS 17. Jakarta: PT Elex Media Komputindo.

Slameto. 2003. Belajar dan Faktor-faktor Yang Mempengaruhinya. Jakarta: Rineka Cipta.

Sudjana, Nana. 1995. Penilaian Hasil Proses Belajar. Bandung: Remaja Rosdakarya.

Sugiyono. 2002. Statistik untuk Penelitian. Bandung: CV Alfabeta.

Sukmadinata, Nana Syaodih. 2005. Metode Penelitian Pendidikan. Jakarta: Rosdakarya.

Supardi. 2008. Diktat Kuliah: Aplikasi Statistik dalam Penelitian Pendidikan. Jakarta: Program Pasca Sarjana UNINDRA.

Supranto, J., 2000. Teknik Sampling. Jakarta: Rineka Cipta.

Syah, Muhibbin. 1995. Psikologi Pendidikan Dengan Pendekatan Baru. Bandung: Remaja Rosdakarya.

The Liang Gie. 1994. Cara Belajar Yang Efisien. Yogyakarta: PUBIB.

Widyastuti, Nurprapti Wahyu. Modul Metode Penelitian Sosial. kk.mercubuana.ac.id/files/99022-12-565587375696.doc. 1 Juli 2013.

Wittig, Arno F. 1981, Psychology of Learning. Schaum's out-line Series. New York:

MC. Grow Hill Book Company.

Winkel, W.S., 1996. Psikologi Pengajaran. Jakarta: PT Gramedia. 2004. Psikologi Pengajaran. Yogyakarta: Media Abadi. 